\title{
Civil liability: characterization of the demand for lawsuits against dentists
}

\section{Alice Aquino $\mathrm{ZANIN}^{(a)}$ Lara Maria HERRERA(b) Rodolfo Francisco Haltenhoff MELANI(a)}

\footnotetext{
(a) Universidade de São Paulo - USP, School of Dentistry, Department of Community Dentistry, São Paulo, SP, Brazil

(b) Universidade Estadual de São Paulo UNESP, School of Dentistry of Araraquara, Araraquara, SP, Brazil
}

\begin{abstract}
In light of the fact that dentists may be held civilly liable for their practice, it is important to understand the current situation of lawsuits filed against these professionals by studying current legal decisions and the literature. The objective of this study was to analyze the case law of the Court of Justice of São Paulo, Brazil, relative to the profile of patients and professionals, the most commonly involved specialties, the amounts litigated and the court decisions pertaining to civil liability lawsuits against dentists. In an inductive approach, a single researcher screened and collected civil liability rulings by accessing the Court's website, and following a statistical-descriptive procedure and an indirect observation technique. The most frequently involved specialty was prosthodontics. However, oral and maxillofacial surgery was related to a higher incidence of damages awarded to settle claims and to higher damage amounts. The dentist was found guilty in $44.32 \%$ of the cases researched. Pecuniary damages ranged between $\mathrm{R} \$ 485.50$ and $\mathrm{R} \$ 12,530.00$, and non-pecuniary damages ranged between $R \$ 2,500.00$ and $R \$ 70,000.00$. Most lawsuits were filed by women against male dentists. An increase in the relative number of lawsuits against companies versus individuals was observed.
\end{abstract}

Keywords: Forensic Dentistry; Liability, Legal; Jurisprudence; Malpractice.

\section{Introduction}

The number of lawsuits against dentists has increased in recent years. This fact can be ascertained by analyzing and comparing surveys conducted by De Paula et al. ${ }^{1}$ and by Wanderley and Lima et $a .^{2}$ in the Courts of Justice of Brazilian states, with an increase of more than $380 \%$ between 2000 and 2011. This phenomenon may be attributed to an increase in the number of healthcare professionals and, consequently, in the number of clinics; to an increase in the share of the population that has access to dental services; to a population who is more knowledgeable of their rights, and who, therefore, pursues legal action more often ${ }^{3,4}$; and to the growth in the number of lawyers specialized in this area ${ }^{5,6}$. According to Ferrara ${ }^{7}$, the increase observed in the number of lawsuits results from post-modern Western society's cultural, social, structural and economic factors.

In the cases of civil liability against dentists, the Brazilian Civil Code ${ }^{8}$ (CC), Civil Procedure Code ${ }^{9}$ (CPC), Consumer Defense Code $^{10}$ (CDC) and Dental Ethics Code $^{11}$ (CEO) are applied. The $\mathrm{CC}^{8}$, Article 186, states that 
"if an individual's actions or voluntary omission, negligence or imprudence, cause damage or losses to another, even if such damages or losses are exclusively non-pecuniary, he will be committing an illegal act." Thus, if there is any causal link between the professional's action or omission and the damage caused, as long as guilt is ascertained (Article 14, paragraph 4 of the $\mathrm{CDC}^{10}$ ), the dentist will incur the liability for said fact, generating an obligation to compensate ${ }^{2,8}$. The $\mathrm{CEO}^{11}$, Article 9, paragraph XIV, establishes the fundamental obligation of dentists to take responsibility for their actions.

When the elements of civil liability (harmful fact, damage and nexus of causality) have been proven, the compensation amount shall be arbitrated. Compensatory damages may be pecuniary or non-pecuniary. Pecuniary (or material) damages are those related to the plaintiff's estate. It consists of an individual's group of legal economically appreciable relationships ${ }^{8}$.

Non-pecuniary (or moral) damages, according to Cavalieri Filho ${ }^{12}$, are those related to the violation of the right to dignity, in the strictest sense, and the violation of any right or personality attribute, in the broadest sense. Moral damage is considered to be pain, shame, suffering or humiliation that, being removed from normalcy, intensely interferes in the individual's psychological behavior, causing affliction, anguish and disruption in his/her well-being and health.

In light of the fact that dentist may be held civilly liable for their practice, irrespective of the dental specialty involved, it is important to understand the current situation of lawsuits filed against these professionals with the aim of preventing their occurrence. This objective can be met by studying current court decisions and comparing them with those described in previous studies on the same subject.

Therefore, the objective of this study was to analyze the case law of the Court of Justice of the State of São Paulo, SP, Brazil, relative to the profile of patients and professionals, the most commonly involved specialties, the litigated amounts, and the court decisions pertaining to civil liability lawsuits against dentists. An additional aim of the study was to correlate specialty involved with court decisions and compensation amounts.

\section{Methodology}

An inductive approach was used, following a statistical-descriptive procedure and an indirect observation technique. A document analysis was conducted by researching all court decisions related to civil liability lawsuits against dentists from May 1, 2013 to April 30, 2014. The case files were retrieved from the website of the Court of Justice of the State of São Paulo (www.tjsp.jus.br). The search query "liability AND civil AND dentist" was used in the "search" field on the website, generating 262 results.

Data collection consisted of three steps: first, screening of abstracts using the search tool; second, selection of abstracts through analysis of the grounds on which the claims were made; and, finally, a detailed reading of the full text of the legal cases. In the second step, the abstracts were read, and 97 cases related to dental malpractice were selected. Other cases $(n=165)$ were excluded because they were not directly related to malpractice, for example, claims for compensation due to car accident with tooth loss, etc.

In the third step, a quantitative analysis was conducted by a single researcher, who tabulated the following information extracted from the text of the judgement in each case: a) the specialty involved in the lawsuit; b) compensation amounts for pecuniary and/or non-pecuniary damages; c) the court's decision (claim accepted or dismissed); and d) profile of the patients and dentists involved in the lawsuit (gender, and whether corporate entity or individual).

\section{Results}

\section{Dental specialties involved}

The most frequent dental specialties involved in lawsuits were prosthodontics, oral and maxillofacial surgery, orthodontics and implantology (Figure). Those cases in which the specialties were not specified were tabulated under the "others" category for data presentation purposes.

\section{Compensation amounts}

All the cases in which the lawsuit was accepted and the damages stipulated therefor were listed for analysis of the compensation amounts, totaling 
43 cases (Table 1). The data were distributed by specialties, from the most cited to the least cited. Pecuniary damages ranged from R $\$ 485.50$ to $\mathrm{R} \$ 12,530.00$, and non-pecuniary (moral) damages ranged from $\mathrm{R} \$ 2,500.00$ to $\mathrm{R} \$ 70,000.00$. In $37 \%$ of the latter cases, amounts ranged from $\mathrm{R} \$ 5,000.00$ to $\mathrm{R} \$ 10,000.00$.

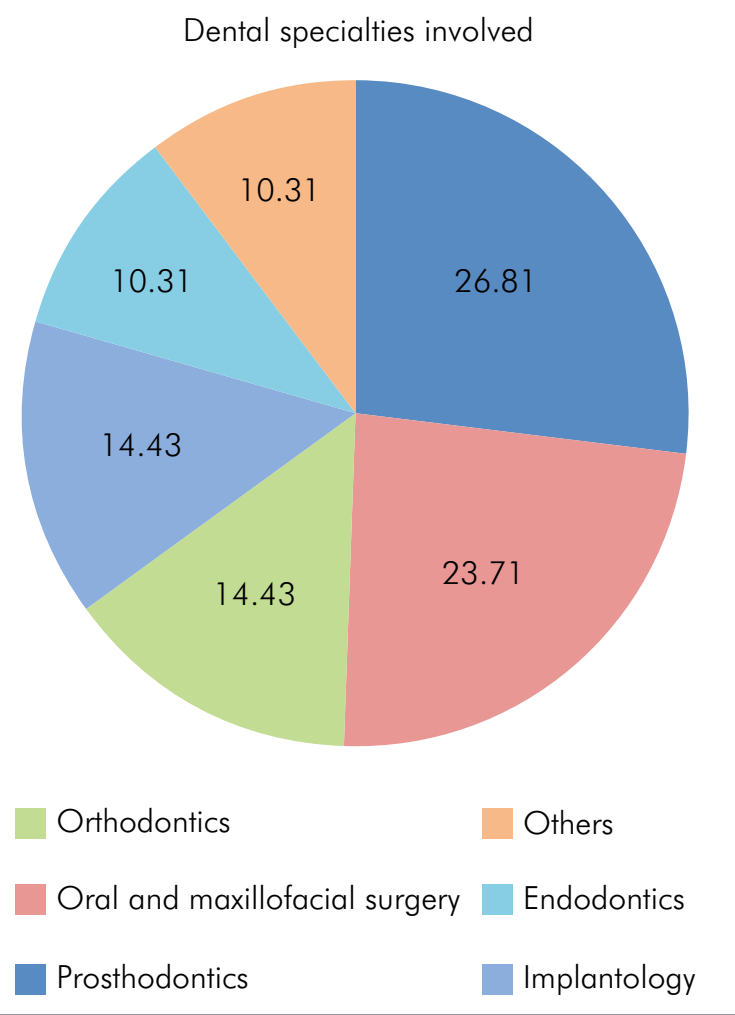

Figure. Percent distribution of the most frequently involved specialties in the lawsuits analyzed.
Only those amounts already stipulated in monetary value were considered in the analysis, and are presented in Table 1.

\section{Profile of patients and professionals}

All the lawsuits were filed by individuals. Among the plaintiffs, 72 were female, 22 were male, and 3 were couples (one male and one female).

As for the defendants, 49 were individuals, involving 34 males, 14 females and 1 couple. Forty-eight were companies. A joinder was involved in 21 cases, 11 of which involving male and 10 , female dentists.

\section{Discussion}

The objective of this study was to characterize the demand for civil lawsuits against dentists in the State of São Paulo, from May 1, 2013 to April 30, 2014. Currently, the Consolidation of Norms for Procedures in Dentistry Boards ${ }^{13}$ includes 19 specialties. In this study, the "specialty" was considered the motive for the case, and the related facts narrated in the complaint indicated discontent by the patient with the results of a particular treatment in that specialty.

The specialties most frequently involved in the cases analyzed were prosthodontics, oral and maxillofacial surgery, orthodontics, and implantology, in this order. The first two specialties corresponded to $50.52 \%$ of the lawsuits, and orthodontics and implantology were related to $14.43 \%$ each. Endodontics was the least frequently involved specialty. These

Table 1. Distribution of cases according to specialty, convictions and claim amounts (maximum and minimum values for pecuniary and non-pecuniary damages).

\begin{tabular}{|c|c|c|c|c|c|c|c|}
\hline \multirow[t]{2}{*}{ Specialty } & \multirow{2}{*}{$\begin{array}{l}\text { Total cases } \\
(\mathrm{n}=97)\end{array}$} & \multirow{2}{*}{$\begin{array}{l}\text { Total convictions } \\
\qquad(\mathrm{n}=43)\end{array}$} & \multirow[t]{2}{*}{$\%$} & \multicolumn{2}{|c|}{$\begin{array}{c}\text { Amounts awarded for pecuniary } \\
\text { damages }\end{array}$} & \multicolumn{2}{|c|}{$\begin{array}{c}\text { Amounts awarded for non-pecuniary } \\
\text { damages }\end{array}$} \\
\hline & & & & Minimum & Maximum & Minimum & Maximum \\
\hline Prosthodontics & 26 & 12 & 46.15 & $R \$ 1,200.00$ & $\mathrm{R} \$ 7,000.00$ & $R \$ 3,000.00$ & $R \$ 21,000.00$ \\
\hline OMS & 23 & 15 & 65.21 & $R \$ 485.50$ & $R \$ 10,595.35$ & $R \$ 2,500.00$ & $R \$ 70,000.00$ \\
\hline Implantology & 14 & 6 & 42.85 & $R \$ 2,466.32$ & $\mathrm{R} \$ 9,048.00$ & $R \$ 8,000.00$ & $R \$ 40,000.00$ \\
\hline Orthodontics & 14 & 6 & 42.85 & $\mathrm{R} \$ 550.00$ & $R \$ 5,516.88$ & $R \$ 3,000.00$ & $R \$ 28,900.00$ \\
\hline Endodontics & 10 & 2 & 20.00 & $R \$ 1,428.00$ & $R \$ 3,700.00$ & $R \$ 2,800.00$ & $R \$ 13,300.00$ \\
\hline Others & 10 & 2 & 20.00 & $R \$ 1,930.00$ & $R \$ 12,530.00$ & $R \$ 6,263.43$ & $R \$ 15,000.00$ \\
\hline
\end{tabular}

OMS: oral and maxillofacial surgery. 
results are in accordance with the majority of studies conducted by other authors ${ }^{1,2,3,14,15,16,17,18}$, indicating that prosthdontics, oral and maxillofacial surgery and orthodontics are the specialties mostly involved in civil liability lawsuits. On the other hand, they diverge in relation to the order in which these specialties rank, as can be seen in Table 2 .
According to Cruz and $\mathrm{Cruz}^{6}$, orthodontics, prosthodontics and implantology are the dental areas with the highest number of lawsuits in Courts, for the following reasons: the procedures involved are more costly; the treatments are generally longer and involve aesthetics (the requirements of which are considered to be more subjective); they all have

Table 2. Specialties most frequently involved in civil liability lawsuits against dentists.

\begin{tabular}{|c|c|c|c|}
\hline Plaintiff & Location & Period & Specialties \\
\hline \multirow{4}{*}{ De Paula et al. ${ }^{1}$} & \multirow{4}{*}{ Brazilian State Courts of Justice } & \multirow{4}{*}{1974 to 2006} & OMS (32.9\%) \\
\hline & & & Prosthodontics (26.4\%) \\
\hline & & & Orthodontics (15.6\%) \\
\hline & & & Implantology (13\%) \\
\hline \multirow{4}{*}{ Melani et al. ${ }^{3}$} & \multirow{4}{*}{ Personal cases } & \multirow{4}{*}{1991 to 2007} & Prosthodontics (48.7\%) \\
\hline & & & Orthodontics (19.51\%) \\
\hline & & & OMS (9.75\%) \\
\hline & & & Endodontics (7.32\%) \\
\hline \multirow{4}{*}{ Biørndal and Reit ${ }^{14}$} & \multirow{4}{*}{ Denmark } & \multirow{4}{*}{2000 to 2004} & Prosthodontics (33\%) \\
\hline & & & Endodontics (13.1\%) \\
\hline & & & Stomatology (1 1.9\%) \\
\hline & & & Restorative dentistry (12.8\%) \\
\hline \multirow{4}{*}{ Wanderley and Lima et al. ${ }^{2}$} & \multirow{4}{*}{ Brazilian State Courts of Justice } & \multirow{4}{*}{2006 to 2011} & Implantology (1 1.53\%) \\
\hline & & & Prosthodontics (9.3\%) \\
\hline & & & Orthodontics (9.2\%) \\
\hline & & & OMS (8.41\%) \\
\hline \multirow{3}{*}{ Rosa et al. ${ }^{15}$} & \multirow{3}{*}{ São Paulo } & \multirow{3}{*}{2007 to 2010} & Implantology (22\%) \\
\hline & & & Orthodontics (21\%) \\
\hline & & & Prosthodontics (20\%) \\
\hline \multirow{3}{*}{ Fernandes and Júnior ${ }^{16}$} & \multirow{3}{*}{ Rio Grande do Sul } & \multirow{3}{*}{2007 to 2010} & OMS (25.4\%) \\
\hline & & & Orthodontics (22.4\%) \\
\hline & & & Prosthodontics (16.4\%) \\
\hline \multirow{4}{*}{ Castro et al. ${ }^{17}$} & \multirow{4}{*}{ Midwest Brazil } & \multirow{4}{*}{2008 to 2010} & Endodontics (28\%) \\
\hline & & & Orthodontics (19\%) \\
\hline & & & OMS (19\%) \\
\hline & & & Prosthodontics (19\%) \\
\hline \multirow{4}{*}{ Terada et al. ${ }^{18}$} & \multirow{4}{*}{ Ribeirao Preto (state of São Paulo) } & \multirow{4}{*}{-} & Prosthodontics (35.6\%) \\
\hline & & & Implantology (26.6\%) \\
\hline & & & Endodontics (15.5\%) \\
\hline & & & Orthodontics (8.8\%) \\
\hline \multirow{4}{*}{ This study } & \multirow{4}{*}{ São Paulo } & \multirow{4}{*}{2013 to 2014} & Prosthodontics (26.81\%) \\
\hline & & & OMS (23.71\%) \\
\hline & & & Orthodontics (14.43\%) \\
\hline & & & Implantology (14.43\%) \\
\hline
\end{tabular}

OMS: oral and maxillofacial surgery. 
procedures deemed controversial at times; and there are a greater number of professionals working without adequate training.

According to Santoro et al. ${ }^{19}$, the high number of lawsuits related to prosthodontics can be attributed to the high value that modern society places on aesthetics, especially in the upper front area of the mouth (involving incisors, canines and first premolars). This is also the most exposed area during functional activity. These authors also emphasize that patients must be forewarned that a dental prosthesis may never be entirely satisfactory aesthetically, and that aesthetics is only one of the objectives of prosthodontic treatment.

The same authors ${ }^{19}$ also assert that an excellent aesthetic result in implantology is not that easy to achieve, for two reasons: the first is the difficulty to restore the fine line of soft gingival tissue, and the second is that the soft tissues do not adhere to the implant as they do to the dental surface, thus running the risk of leaving the implant's metallic margin exposed.

Dental treatments create great expectations in patients. The opportunity of gaining improved function and/or aesthetics involves an oftentimes long process, which needs to be monitored by a professional, observing not only the biological characteristics and responses, but also the patient's behavior observed during the treatment sessions. Maintaining appropriate dental records that include the proposed treatment plan is also essential for establishing evidence in the course of a lawsuit ${ }^{20}$.

The dentist was found guilty in $44.32 \%$ of the cases researched. This result is in accordance with those found by Bjørndal and Reit ${ }^{14}(43 \%)$ and Castro et al. ${ }^{17}(47 \%)$. Even though prosthodontics was the most common specialty involved in civil liability lawsuits $(n=26)$, the obligation to pay damages was observed in only $46.15 \%$ of these cases. Oral and maxillofacial surgery was the second most cited specialty in litigation ( $n=23)$, but damages for malpractice were awarded in $65.21 \%$ of these cases. Claim amounts were also higher than those for prosthodontics, with the highest amount of pecuniary damages set at $\mathrm{R} \$ 10,959.35$ and non-pecuniary damages, at $\mathrm{R} \$ 70,000.00$ (Table 1).
In a study of 101 civil liability cases in Italy, Montagna et al. ${ }^{21}$ found that the specialties with the highest compensation averages, in descending order, were temporomandibular dysfunction, prosthodontics, oral and maxillofacial surgery, and implantology, but that the highest absolute amounts were found in oral and maxillofacial surgery.

Knaak and Parzeller ${ }^{22}$ stated that there is a trend in Germany for patients to seek high amounts in lawsuits involving the medical and dental areas. In Brazil, Fernandes et al. ${ }^{23}$ concluded that there is a tendency among judges to award more claims for non-pecuniary versus pecuniary damages in the dental area, and to award higher amounts for aesthetic damages.

After analyzing the decisions from the Court of Justice of the State of São Paulo, Rosa et al. ${ }^{15}$ ascertained that pecuniary damages ranged from $\mathrm{R} \$ 80.00$ to $\mathrm{R} \$ 34,270.00$ and non-pecuniary damages ranged from $\mathrm{R} \$ 3,500.00$ to $\mathrm{R} \$ 324,000.00$. In this study, the amounts awarded for non-pecuniary damages were also higher than those for pecuniary damages ( $\mathrm{R} \$ 485.00$ to $\mathrm{R} \$ 12,530.00$ for pecuniary damages, versus $R \$ 2,500.00$ to $R \$ 70,000.00$ for non-pecuniary damages; Table 1). However, in Midwest Brazil the amounts were lower, with pecuniary damages ranging from $R$ \$2,000.00 to $R \$ 25,000.00$ and non-pecuniary damages ranging from $R \$ 329.95$ to $R \$ 12,080.00^{17}$. In the city of Ribeirão Preto (state of Sao Paulo), the amounts awarded for pecuniary and non-pecuniary damages ranged from $\mathrm{R} \$ 2,330.00$ to $\mathrm{R} \$ 14,150.00^{18}$.

When establishing non-pecuniary (or moral) damages, the following criteria should be considered: intensity of suffering and level of deceitfulness, severity of the offense and its repercussion, offender's economic situation, and deterrence of the reiterated practice of the illegal act ${ }^{24}$. However, Article 944, sole paragraph, of the Civil Code stipulates that "if there is an excessively disproportionate relationship between the level of guilt and the severity of damage, the judge may reduce the compensation accordingly." Therefore, fortune-making without cause is not admitted.

According to Verçosa and Melani ${ }^{25}$, "the fact that judges can award amounts for damages at their discretion has resulted in major discrepancies in stipulated amounts, especially when non-pecuniary 
damages are involved." These authors propose using a table system for setting the values for bodily damage, to be used as a "fixed" reference so that the judge does not overstep himself far beyond reality in his ruling. It is noteworthy that, in recent rulings, the Brazilian Superior Court of Justice (STJ) adopted a compensation parameter of $R \$ 50,000.00$ to $R \$ 200,000.00$ for cases in which there was serious, disabling or irreversible injury ${ }^{26-28}$.

The aforementioned authors ${ }^{25}$ analyzed 30 decisions from the Courts of Justice of Brazilian states related to the loss of front teeth, between 2005 and 2010, and found that the claim amounts (pecuniary plus non-pecuniary damages) ranged from $R \$ 2,246.76$ to $\mathrm{R} \$ 31,101.00$, for the loss of one tooth. These values are close to those found in the present study, namely from $\mathrm{R} \$ 2,500.00$ to $\mathrm{R} \$ 27,592.00$ for the loss of one tooth, regardless of location.

Aesthetic damages are admitted in cases of physical deformities that cause distortions or repugnance, in cases of scars and other physical defects that cause the plaintiff to feel distress or have an inferiority complex. In the STJ, an understanding prevails according to which aesthetic damage differs from psychological damage (the latter being related to the awarding of non-pecuniary damages). The former corresponds to a morphological change in the body that is displeasing to the eye, causing repulsion, whereas the latter, to mental suffering, "pain in the soul," affliction and anguish to which the victim is submitted, and which can be arbitrated simultaneously or individually ${ }^{12}$.

In the present study, only one case of valuation of transitory aesthetic damage was reported, separately from valuation of the non-pecuniary damage involved. The amount awarded was $\mathrm{R} \$ 1,356.00$ (corresponding to two minimum wages at the time of the decision), in a case of extraction of the wrong tooth, namely a maxillary second molar, rather than a maxillary third molar. The patient was a photographic model, and the amount was considered moderate by the court, because it involved transitory damages of a lesser degree ${ }^{29}$.

In relation to the profile of the plaintiffs, there was a predominance of women (74\%), as in the studies by Montagna et al. ${ }^{21}(68 \%)$, Knaak and Parzeller ${ }^{22}$ (56\%), Rosa et al. ${ }^{15}(73 \%)$, and Castro et al..$^{17}(79 \%)$.
Rosa et al. ${ }^{15}$ suggested that this phenomenon occurs because women are more willing to confront their difficulties with dental professionals. Women tend to take better care of their health and are responsible for a major share of the consumer market, including the oral healthcare services market.

In relation to the profile of defendants in the individuals category $(\mathrm{n}=49)$, most of them were men (69\%), which is in accordance with the results of Montagna et al. ${ }^{19}$, Rosa et al. ${ }^{15}$, and Castro et al. ${ }^{17}$, who reported values of $93 \%, 76 \%$ and $53 \%$, respectively. Men are sued more often on the grounds of ethical issues as well, as observed by Pacheco et al. ${ }^{4}$, who found that male dentists represented $59.2 \%$ of cases in an analysis of 529 ethical lawsuits filed in the state of Espírito Santo.

According to a statistical report of June 11, 2014, there are 81,860 active dentists registered at the Regional Board of Dentistry of São Pauloi, 48,014 of whom are women $(58.6 \%)$ and 33,846 , men $(41.4 \%)$. Therefore, even though women outnumber men in the dental profession, men outnumber women as defendants in malpractice lawsuits. This may be due to the psychological and behavioral differences that exist between genders that generally lead to women performing verbal tasks (language and communication) better than men ${ }^{30}$, thereby allowing for an improved relationship with their patients.

This study found 48 lawsuits where the defendant was a corporate entity. Cavalcanti et al. ${ }^{31}$ found only one lawsuit against an individual (out of 82 administrative proceedings filed at PROCON, a Consumer Protection Agency in Brazil), and the remainder against dental plans, low-income clinics and other health plans. On the other hand, Rosa et al. ${ }^{15}$ found that only 8 lawsuits of the 82 cases studied involved companies, from 2007 to 2010, as filed at the Court of Justice of the State of São Paulo.

This increase in the number of lawsuits lodged against companies in the courts probably occurs as a result of greater chances for compensation, because, by law, companies share responsibility with the professionals who work for the company. In other words, the consumer has the right to sue the company

CRO-SP. Contact Us [personal message] Message received by <faleconosco@crosp.org.br> on November 6, 2014. 
and the professional providing the services, with each answering to the totality of damages caused ${ }^{8,9,12}$.

\section{Conclusion}

The specialty most involved in the lawsuits against dentists was prosthodontics, whereas the specialty associated with the highest rate of conviction for professional malpractice and with

\section{References}

1. De Paula FJ, Motta MV, Bersácola RN, Muñoz DR, Silva M. [Scenario of civil liability actions against dentists in Brazilian courts]. Rev Paul Odontol. 2010;32(4):22-8. Portuguese.

2. Lima RBW, Moreira VG, Cardoso AMR, Nunes FMR, Rabello PA, Santiago BM. [Jurisprudence' survey of civil liability cases against dentists in Brazilian courts of justice]. Rev Bras Ciênc Saúde. 2012;16(1):49-58. Portuguese.

3. Melani RFH, Oliveira RN, Tedeschi-Oliveira SV, Juhás R. [Legal devices and arguments mostly used in civil lawsuits: casuistry analysis in Dentistry]. RPG Rev Pos Grad. 2010;17(1):46:53. Portuguese.

4. Pacheco KTS, Silva Junior MF, Meireles NR. Ethical proceedings against dentists in Espírito Santo for infringements to the code of dental ethics. Braz Oral Res. 2014;28(1):1-7. doi:10.1590/1807-3107BOR-2014.vol28.0002

5. Garbin CAS, Garbin AJI, Rovida TAS, Saliba MTA, Dossi AP. [The professional responsibility of dentist in lawyer's opinion]. Rev Odontol UNESP. 2009;38(2):129-34. Portuguese.

6. Cruz RM, Cruz CPAC. [Risk management in orthodontic practice: how to avoid legal problems]. Dental Press. 2008;13(1):141-56. Portuguese.

7. Ferrara SD. Medical malpractice and legal medicine. Int J Legal Med. 2013;127:541-4. doi:10.1007/s00414-013-0839-2

8. Brazil. ei $\mathrm{n}^{\mathrm{o}} 10.406$, de 10 de janeiro de 2002. Institui o Código Civil. Diário Oficial União. 2002 Jan 11.

9. Brazil. Lei $n^{0} 5.869$, de 11 de janeiro de 1973. Institui o Código de Processo Civil. Diário Oficial União. 1973 Jan 17.

10. Brazil. Lei n $^{\circ} 8.078$, de 11 de setembro de 1990. Dispõe sobre a proteção do consumidor e dá outras providências. Diário Oficial UNião. 2007 Jan 10.

11. Conselho Federal de Odontologia. Resolução 118. Revoga o Código de Ética Odontológica aprovado pela Resolução CFO n ${ }^{\circ}$ 42/2003 e aprova outro em substituição. Diário Oficial União. 2012 June 14.

12. Cavalieri Filho S. Programa de responsabilidade civil. 11a ed. São Paulo: Atlas; 2014. Chapter 4, Responsabilidade extracontratual subjetiva: pressupostos: o dano, p. 91-174. the highest compensation was Oral Maxillofacial Surgery. The amounts awarded for pecuniary damages were higher than the amounts awarded for non-pecuniary damages.

A predominance of women versus men was observed as plaintiffs of lawsuits against male dentists, with a significant increase in lawsuits against companies.

13. Conselho Federal de Odontologia. Consolidação das normas para procedimentos nos conselhos de odontologia: aprovada pela resolução CFO-63/2005. Rio de Janeiro: Conselho Federal de Odontologia; 2012.

14. Bjørndal L, Reit C. Endodontic malpractice claims in Denmark 1995-2004. Int Endod J. 2008;41(12):1059-65. doi:10.1111/j.1365-2591.2008.01455.x

15. Rosa FM, Fernandes MM, Júnior ED, Paranhos LR. [Material and moral damages in cases involving dentists in the state of São Paulo]. RFO UPF. 2012;17(1):26-30. Portuguese.

16. Fernandes MM, Daruge Júnior E. [Dental specialties most involved in lawsuits]. CRO-RS Notíciais. 2012;43(2):8-9. Portuguese.

17. Castro ACC, Franco A, Silva RF, Portilho CDM, Oliveira HCM. Prevalence and content of legal suits founded on dental malpractice in the courts of Midwest Brazil. Rev Bras Odontol Legal. 2015;2(1):46-52. doi:10.21117/rbol.v2i1.20

18. Terada ASSD, Araujo LG, Flores MRP, Silva RHA. [Civil liability of dental surgeon: legal proceedings analysis in the city of Ribeirao Preto, São Paulo State, Brazil]. Int J Odontostomat. 2014;8(3):365-9. Spanish. doi:10.4067/S0718-381X2014000300008

19. Santoro V, De Donno A, Dell'Erba A, Introna F. Esthetics and implantology: medico-legal aspects. Minerva Stomatol. 2007;56(1-2):45-51.

20. Zanin AA, Strapasson RAP, Melani RFH. [Case law study: evidence presented in civil liability lawsuits against dentists]. Rev Assoc Paul Cir Dent. 2015;69(1):74-79. Portuguese.

21. Montagna F, Manfredini D, Nuzzolese E. Professional liability and structure of litigation in dentistry. Minerva Stomatol. 2008;57(7-8):349-57.

22. Knaak JP, Parzeller M. Court decisions on medical malpractice. Int J Legal Med. 2014;128(6):1049-57. doi:10.1007/s00414-014-0976-2

23. Fernandes MM, Bouchardet FCH, Tavares GSV, Júnior ED, Paranhos LR. [Forensic dentistry aspects related to aesthetic damages in court cases judged in Rio Grande 
- Civil liability: characterization of the demand for lawsuits against dentists

do Sul State]. Odonto. 2012;20(40):7-12. Portuguese. doi:10.15603/2176-1000/odonto.v20n40p7-12

24. Brazil. Superior Tribunal de Justiça (2013). Ap. 0055118-66.2003.8.26.0224. Relator: Luiz Ambra.

25. Verçosa CB, Melani RFH. [Tables as a reference for establishing compensation amounts for dental damages]. Rev Assoc Paul Cir Dent. 2011;65(6)426-9. Portuguese.

26. Brazil. Superior Tribunal de Justiça (2013). AgRg no AREsp 318.131/SP. Relator: Sidnei Beneti.

27. Brazil. Superior Tribunal de Justiça (2012). AgRg no AREsp 221.113/RJ. Relator: Herman Benjamin.

28. Brazil. Superior Tribunal de Justiça (2010). REsp 808.601/RS. Relator: Sidnei Beneti.
29. Brazil. Superior Tribunal de Justiça (2013). Ap. 9191422-67.2007.8.26.0000. Relator: Pedro de Alcântara da Silva Leme Filho.

30. Ngun TC, Ghahramani N, Sánchez FJ, Bocklandt S, Vilain E. The Genetics of sex differences in brain and behavior. Front Neuroendocrinol. 2011;32(2):227-46. doi: 10.1016/j.yfrne.2010.10.001

31. Cavalcanti AL, Ó Silva AL, Santos BF, Azevedo CKR, Xavier AFC. [Dentistry and the Consumer Defense Code: analysis of the lawsuits against dentists and dental insurance plans in Campina Grande, PB, Brazil]. Rev Odontol UNESP. 2011;40(1):6-11. Portuguese. 